\title{
The influence of continuous subcutaneous insulin infusion therapy vs. multiple daily injections upon the diet of those with Type 1 diabetes: A food diary investigation
}

\author{
R.J. Webb ${ }^{1}$, I.G. Davies ${ }^{1}$, T.S. Purewal ${ }^{2}$, P.J. Weston ${ }^{2}$, G. Morrison ${ }^{2}$ and J.C. Abayomi ${ }^{1}$ \\ ${ }^{1}$ Liverpool John Moores University, Faculty of Education, Health \& Community, Barkhill Road, Liverpool, L17 6BD \\ and ${ }^{2}$ Royal Liverpool and Broadgreen University Hospital, Prescot Street, Liverpool, L7 8XP
}

There exist a number of therapeutic options for the management of Type 1 diabetes (T1D). Multiple daily injections (MDI) are one such treatment and involve 4-5 daily subcutaneous injections of insulin. This frequently used approach is widely regarded as an effective method of controlling glycaemia; however, if a patient continues to suffer disabling episodes of hypoglycaemia, or if $\mathrm{HbA}_{1 \mathrm{c}}$ remains above $8.5 \%$ continuous subcutaneous insulin infusion (CSII) may instead be recommended ${ }^{1}$. This therapy employs a small programmable pump device to facilitate the administration of insulin to the patient via a cannula. Various advantages of CSII have been documented compared to MDI, including improvements in glycaemic control and reduced incidence of both hypoglycaemia and the dawn phenomenon. An additional attribute, characterised by the flexible nature of the therapy, is that a liberalised diet may be enjoyed by patients, which in turn may infer potential nutrition and quality of life aberrations. This phenomenon is surprisingly under researched and further investigations to inform both treatment and risk would therefore be beneficial.

Following ethical approval and informed consent patients with T1D using either CSII or MDI from the Royal Liverpool Hospital were asked to complete a 5 day weighed food diary. Dietplan 6 software was used to process the responses and demographic data from participants' medical records were added to the dataset. All data were then interrogated using descriptive statistics and any nonnormal data were transformed logarithmically before further enquiry with $t$-tests or analysed non-parametrically with Mann-Whitney- $U$-tests.

The sample comprised of 20 patients (35\% male, $65 \%$ female) with 11 using CSII and 9 using MDI. The patients' mean age was 49 \pm 16 years and the majority were overweight or obese $(72.7 \% \mathrm{CSII}, 55.6 \% \mathrm{MDI})$.

Table. Selected food diary results from patients using CSII and MDI compared to reference nutrient intakes.

\begin{tabular}{lcccc}
\hline & $\begin{array}{c}\text { Amount per } \\
\text { day (CSII } \\
\text { group) }\end{array}$ & $\begin{array}{c}\text { Amount per } \\
\text { day (MDI } \\
\text { group) }\end{array}$ & $\begin{array}{c}\text { \% energy } \\
\text { intake per } \\
\text { day (CSII } \\
\text { group) }\end{array}$ & $\begin{array}{c}\text { \% energy } \\
\text { intake per } \\
\text { day (MDI } \\
\text { group) }\end{array}$ \\
\hline Energy & $1866.6 \mathrm{Kcal}$ & $2110.5 \mathrm{Kcal}$ & $\mathrm{N} / \mathrm{A}$ & $\mathrm{N} / \mathrm{A}$ \\
Protein & $69.0 \mathrm{~g} /$ day & $89.9 \mathrm{~g} /$ day & 14.8 & $17 \cdot 0$ \\
Total CHO & $232.3 \mathrm{~g} /$ day & $251.8 \mathrm{~g} /$ day & $46 \cdot 7$ & 44.7 \\
Total sugars & $99.8 \mathrm{~g} /$ day & $88.6 \mathrm{~g} /$ day & 20.0 & 15.7 \\
Total fat & $73.5 \mathrm{~g} /$ day & $80.1 \mathrm{~g} /$ day & 35.4 & 34.2 \\
Saturated fat & $31.6 \mathrm{~g} /$ day & $29.8 \mathrm{~g} /$ day & 15.2 & 12.7 \\
\hline
\end{tabular}

Results showed mean energy intake was below the reference nutrient intake (RNI) for the CSII group; potentially suggestive of underreporting (Table $)^{3}$. Patients using both CSII and MDI consumed protein above the RNI; however, this macronutrient contributed towards $14.8 \%$ of the daily energy intake of patients using CSII and $17.0 \%$ of those using $\mathrm{MDI}^{3}$. Total carbohydrate (CHO) consumption was below the RNI of $50 \%$; however, it should be noted that consumption of total sugars was above the RNI for males and females in both groups ${ }^{4}$. Previous research by the authors suggesting habitual fruit consumption, particularly in those using CSII, may explain this ${ }^{5}$. Total fat and saturated fat consumption was mostly synonymic with RNI's. Although no statistically significant associations were seen between any of the variables and the diets of the two populations appeared largely homogenous it is reassuring that no detrimental changes occurred. Despite this further analysis of total energy, protein and CHO quality is warranted.

1. Department of Health (2007) Insulin Pump Services: Report of the Insulin Pumps Working Group

2. Cummins E. et al. (2010) Health Technology Assessment, 14 1-208

3. COMA (1991) Dietary Reference Values of Food Energy and Nutrients for the United Kingdom

4. WHO (2015) Sugar Intake for Adults and Children

5. Webb R.J. et al. (2015) Proceedings of the Nutrition Society, 74 E325 